\title{
First molecular assessment of the African swine fever virus status of Ornithodoros ticks from Swaziland
}

\author{
Authors: \\ Carin I. Boshoff ${ }^{1,2,3}$ \\ Armanda D.S. Bastos ${ }^{2}$ \\ Mzwandi M. Dube ${ }^{4}$ \\ Livio Heath ${ }^{1}$

\section{Affiliations:} \\ ${ }^{1}$ Agricultural Research Council- \\ Onderstepoort Veterinary \\ Institute, Transboundary \\ Animal Diseases Programme, \\ South Africa
}

${ }^{2}$ Mammal Research Institute, Department of Zoology \& Entomology, University of Pretoria, South Africa

${ }^{3}$ Department of Biomedical Sciences, Tshwane University of Technology, South Africa

\section{${ }^{4}$ Central Veterinary}

Laboratory, Ministry of

Agriculture, Swaziland

Correspondence to:

Carin Boshoff

Email:

boshoffci@tut.ac.za

Postal address:

Private Bag X68, Pretoria

0001, South Africa

Dates:

Received: 09 Sept. 2014

Accepted: 03 Oct. 2014

Published: 03 Dec. 2014

How to cite this article:

Boshoff, C.I., Bastos, A.D.S.,

Dube, M.M. \& Heath, L., 2014,

'First molecular assessment of the African swine fever virus status of Ornithodoros ticks from Swaziland',

Onderstepoort Journal of Veterinary Research 81(1), Art. \#846, 5 pages. http://dx.doi. org/10.4102/ojvr.v81i1.846

\section{Copyright:}

(C) 2014. The Authors.

Licensee: AOSIS

OpenJournals. This work is

licensed under the Creative

Commons Attribution License

\section{Read online:}

African swine fever (ASF) is an economically significant haemorrhagic disease of domestic pigs. It is caused by the African swine fever virus (ASFV), a deoxyribonucleic acid (DNA) arbovirus. Argasid ticks of the genus Ornithodoros, which are widely distributed throughout southern Africa, play a primary role in virus maintenance and spread within the endemic sylvatic cycle. The ASF status of Swaziland is unknown, but this land-locked country is surrounded by ASF-positive countries, has a burgeoning pig industry and sylvatic cycle hosts present within its borders. In this first assessment of ASF status, warthog burrows in seven nature reserves and game management areas in Swaziland were investigated for tick and virus presence. Tick infestation rates of between $33.3 \%-88.8 \%$ were recovered for the four Ornithodoros-infested reserves. A total of 562 ticks were screened for virus genome presence using a duplex Polymerase Chain Reaction (PCR) that targets the C-terminal end of the $p 72$ gene of the ASFV and confirms DNA integrity through amplification of the 16S rRNA tick host gene. All samples were negative for virus genome presence and positive for the tick genome target. Nucleotide sequencing of the latter confirmed that Ornithodoros ticks from Swaziland are identical to those from the Kruger National Park in South Africa across the gene region characterised. Whilst this first evaluation of ASF presence in Swaziland indicates that the virus does not appear to be present in the key virus vector, the presence of sylvatic cycle hosts, together with the country's proximity to ASF-affected countries calls for expanded investigations and regular monitoring of the ASF status of Swaziland.

\section{Introduction}

African swine fever (ASF) is an infectious viral haemorrhagic disease of domestic pigs. It is caused by the African swine fever virus (ASFV), the the only known DNA arbovirus and sole member of the Asfarviridae family (King et al. 2012). Warthog-associated argasid ticks of the genus Ornithodoros, which are widely distributed throughout southern Africa, play a primary role in maintenance and spread of the virus within the endemic sylvatic cycle, and virtually all regions in which the sylvatic hosts co-occur are ASF-positive (Jori \& Bastos 2009). The sylvatic cycle of ASFV established between wild suids and ticks allows for the circulation and perpetual maintenance of the virus. Currently, no vaccines are available to control the disease and prevention relies on regulated control zones such as the one in South Africa (Figure 1a), and on strict bio-security measures that prevent contact between domestic pigs and Ornithodoros ticks (Penrith, Thomson \& Bastos 2004).

Swaziland is situated between the KwaZulu-Natal and Mpumalanga provinces of South Africa, to the south and north, respectively; it shares its eastern border with Mozambique (Figure 1a). An important objective of livestock development in Swaziland is to increase animal production to meet the growing demand for animal protein. Recent increases in smallscale pig farming, particularly in communities in close proximity to game reserves containing sylvatic cycle hosts, has signalled the need for assessment of ASF status, as it is an important but unevaluated constraint for pig production. No prior surveys have been conducted; the ASF status of Swaziland is currently unknown and assumed negative, despite the presence of both invertebrate and wild suid species associated with the sylvatic cycle and the encirclement of this land-locked country by ASF-positive regions. As such, Swaziland is currently considered to be an area that is under constant threat of incursion, but if found to be ASF-positive, can potentially also serve as an uncontrolled reservoir of infection. This present survey was therefore undertaken to determine the distribution of sylvatic cycle Ornithodoros ticks and possible presence of the virus in this invertebrate reservoir. The results of the study are crucial for formulation of appropriate disease-control strategies for this and neighbouring countries, and complement ongoing efforts by the Swaziland government and the Food and Agriculture Organization (FAO), with support of the European Union (EU), to reverse the country's declining agricultural productivity and to increase pig production (FAO 2011). 


\section{Materials and methods}

\section{Swaziland as the study area}

Swaziland is the smallest country in Africa, and is bordered in the north, west and south by South Africa and by Mozambique in the east. It has a land area of just over $17000 \mathrm{~km}^{2}$ and contains four separate geographical regions that run from north to south. These regions vary in altitude from 1800 m.a.s.l. - 200 m.a.s.l. Along the eastern border with Mozambique, the Lubombo mountain ridge has an altitude of around $600 \mathrm{~m}$. Along the north-western border, the rainforest highveld region, with an average altitude of $1200 \mathrm{~m}$, lies on the edge of the escarpment; the middleveld has an average altitude of 700 m.a.s.l., with the lowveld of Swaziland being around 250 m.a.s.l. Swaziland's climate ranges from temperate to subtropical. The weather depends on the region of the country, with the lowland areas being subtropical, with temperatures reaching up to $42{ }^{\circ} \mathrm{C}$ during peak summer, whereas at higher altitudes in the highveld regions, temperatures in summer average $20{ }^{\circ} \mathrm{C}$ and the weather is cloudy and cool. Rain falls mostly during the summer months, with the winter months of June-August being dry. Annual rainfall is highest on the highveld in the west, with between $1000 \mathrm{~mm}$ - $2000 \mathrm{~mm}$ being recorded, with the lowveld in the east recording between $500 \mathrm{~mm}-900 \mathrm{~mm}$ per annum (Atlapedia 1993-2011; Embassy of the Kingdom of Swaziland 2014).

\section{Study design}

In Swaziland, there are national, private and communityowned protected areas including national parks, nature reserves, wildlife sanctuaries and game reserves. For the present study, access was granted for sampling in seven nature reserves and game parks (Table 1), and included parks located near the borders with South Africa and Mozambique. These parks form part of the SongimveloMalolotja Transfrontier Conservation Areas (TFCA) and the Lubombo Conservancy, which incorporate South Africa and Mozambique, respectively. As warthog censuses have not been performed, exact numbers of these sylvatic vertebrate host species are unknown for the seven parks included in the present study.

In order to ensure consistency between sampling opportunities, a single team consisting of a sampling team leader and field assistant performed the collection under the field guidance of a knowledgeable ranger at each specific park. Estimated collection days per park were determined based on the size of a park, with a maximum of 5 days and a minimum of 2 days being allocated for Hlane (22 000 ha) and Mbuluzi (3000 ha), respectively. Storm water pipes on dirt and tarred roads, and anthills near roads, which can both serve as overnight warthog shelters, as well as warthog burrows in the field, were inspected for tick presence.

\section{Tick collection}

Ticks were collected according to a modified manual collection method (Jori et al. 2013). Briefly, sand was collected from each burrow and spread in a thin layer across a large black plastic sheet, which was placed in the sun. As soft ticks are photophobic and do not tolerate warm temperatures, this encourages Ornithodoros tick movement and facilitates tick detection and collection. A minimum time span of 30 min per burrow was allowed, to ensure that tick movement was elicited and that all visible ticks were collected. Ticks were hand-picked, labelled and transported to the Onderstepoort Veterinary Institute, Transboundary Animal Disease Programme (OVI-TADP) laboratory for analysis, in sealed containers, under the necessary permits. Individual ticks were temporarily incapacitated by refrigeration, photographed and sorted microscopically into the various nymphal stages. Adult ticks were sorted on the basis of gender, and each tick was placed in an individual, labelled tube.

\section{Molecular analysis}

Individual ticks were weighed and placed into $1.5 \mathrm{~mL}$ Eppendorf tubes and frozen for $10 \mathrm{~min}$ at $-86^{\circ} \mathrm{C}$ prior to the addition of phosphate-buffered saline (PBS). Each tick was ground with a pestle and DNA was extracted from $100 \mu \mathrm{L}$ of the $10 \%$ weight in volume $(\mathrm{W} / \mathrm{V})$ homogenate using a modified silica-guanidium thiocyanate method (Boom et al. 1990). A duplex polymerase chain reaction (PCR), incorporating a tick mitochondrial $16 \mathrm{~S}$ gene target as internal control, was performed when screening for ASFV genome presence (Bastos et al. 2009). By incorporating primers that target the $p 72$ gene of the ASF virus genome and those that target a conserved region of the mitochondrial 16S rRNA gene of Ornithodoros ticks, presence of virus genome and nucleic acid integrity could, respectively, be determined. Genomic amplification was performed in a final volume of

TABLE 1: Game parks and infestation rates of warthog burrows with Ornithodoros ticks in Swaziland.

\begin{tabular}{|c|c|c|c|c|c|c|c|c|}
\hline $\begin{array}{l}\text { Game Reserve } \\
\text { or National Park }\end{array}$ & $\begin{array}{l}\text { Latitude; longitude } \\
\text { co-ordinates for the game } \\
\text { reserves }\end{array}$ & $\begin{array}{l}\text { Region in } \\
\text { Swaziland }\end{array}$ & $\begin{array}{l}\text { Approximate } \\
\text { size of the } \\
\text { game park (ha) }\end{array}$ & $\begin{array}{l}\text { Altitudinal } \\
\text { range across } \\
\text { the park } \\
\text { (m.a.s.l.) }\end{array}$ & Date sampled & $\begin{array}{l}\text { Number of } \\
\text { burrows with } \\
\text { ticks }\end{array}$ & $\begin{array}{l}\text { Number of } \\
\text { burrows } \\
\text { examined }\end{array}$ & $\begin{array}{l}\text { Total } \\
\text { number } \\
\text { of ticks } \\
\text { collected }\end{array}$ \\
\hline Malolotya & $26^{\circ} 08^{\prime} 49.0^{\prime \prime} S, 31^{\circ} 08^{\prime} 16.4^{\prime \prime} \mathrm{E}$ & North-western & 18000 & $1830-640$ & November 2012 & 0 & 11 & 0 \\
\hline Mlilwane & $26^{\circ} 28^{\prime} 40.1^{\prime \prime S}, 31^{\circ} 11^{\prime} 43.7^{\prime \prime} \mathrm{E}$ & Western & 4600 & $1450-670$ & March 2013 & 0 & 4 & 0 \\
\hline Nisela & $26^{\circ} 58^{\prime} 20.3^{\prime \prime S}, 31^{\circ} 56^{\prime} 28.9^{\prime \prime} \mathrm{E}$ & Southern & 4000 & $230-140$ & April 2013 & 0 & 4 & 0 \\
\hline Hlane & $26^{\circ} 16^{\prime} 59.3^{\prime \prime S}, 31^{\circ} 52^{\prime} 44.5^{\prime \prime} \mathrm{E}$ & North-eastern & 22000 & $570-150$ & March 2013 & 3 & 9 & 20 \\
\hline Mkhaya & $26^{\circ} 37^{\prime} 11.7^{\prime \prime S}, 31^{\circ} 45^{\prime} 13.3^{\prime \prime} \mathrm{E}$ & South-eastern & 10000 & $310-225$ & May 2013 & 4 & 8 & 41 \\
\hline Mbuluzi & $26^{\circ} 09^{\prime} 21.8^{\prime \prime S}, 31^{\circ} 58^{\prime} 56.5^{\prime \prime} \mathrm{E}$ & North-eastern & 3000 & $460-150$ & April 2013 & 8 & 13 & 232 \\
\hline Mlawula & $26^{\circ} 12^{\prime} 26.7^{\prime \prime S}, 32^{\circ} 00^{\prime} 10.2^{\prime \prime} \mathrm{E}$ & North-eastern & 16500 & $470-150$ & November 2013 & 8 & 9 & 269 \\
\hline
\end{tabular}


$50 \mu \mathrm{L}$ in the presence of $0.2 \mathrm{mM} \mathrm{dNTP}, 0.5 \mu \mathrm{M}$ of each primer, $1 \mathrm{U}$ thermostable Go Taq G2 DNA polymerase (Promega Corp., Madison, WI, USA) and $3 \mu \mathrm{L}$ of each DNA extract. Thermal cycling conditions prescribed for C-terminal $p 72$ gene amplification (Bastos et al. 2003) were used. The PCR products were evaluated by $1.5 \%$ agarose gel electrophoresis against a 100-bp ladder (Promega Corp., Madison, WI, USA). In this assay, amplification of a $478 \mathrm{bp}$ band confirms virus presence and amplification of the $313 \mathrm{bp}$ host gene target verifies DNA integrity. The DNA fragments of the expected size were excised from the gel and purified. Nucleotide sequences were generated for the tick mitochondrial gene target (Inqaba Biotechnologies, Pretoria, South Africa) of a geographically representative subset of tick samples. The resulting partial $16 \mathrm{~S}$ rRNA sequences, submitted to Genbank under accession numbers KJ940548-KJ940550, were complemented with homologous data prior to phylogenetic inference in Mega 5 (Tamura et al. 2011).

\section{Results}

Ornithodoros ticks were found to be present in four of the seven game reserves that were sampled (Table 1 and Figure 1b). Tick infestation rates varied from $33.3 \%-88.8 \%$ between the four tick-infested parks (Table 1). A total of 562 ticks were collected, of which 105 were female, 113 were male and the remaining 344 were nymphs. All ticks tested by duplex PCR were positive for the host 16S rRNA gene, but negative for ASFV, suggesting that despite the presence of sylvatic cycle hosts, the virus appears to be absent from Ornithodoros ticks in the game reserves that were evaluated.

\section{Discussion}

Ticks were only observed in parks situated in the eastern region of the country and were absent in the parks in the mountainous western region. Swaziland has a bowl-like terrain, being predominantly mountainous with forest escarpments in the north-western side, flattened throughout the centre of the country and becoming mountainous in the north-east along the Mozambique border. The game reserves that were positive for Ornithodoros tick presence all fell within the eastern savannah area and were associated with lower altitude localities (Figure 1b). Despite intensive searching and re-visiting of some of the parks, warthog burrows proved difficult to locate, particularly in the western half of the country, which is mountainous and densely vegetated. These sampling difficulties and the high altitudes likely underlie the comparatively lower number of burrows sampled in Mlilwane and Nisela, and the relatively low overall tick numbers from western Swaziland. Similar difficulties were encountered in Malawi, where large differences in occurrence of Ornithodoros ticks were observed, leading the authors of that study to speculate that altitude may be an important factor influencing tick distribution (Haresnape \& Mamu 1986).

The slight male bias in adult ticks collected in Swaziland is consistent with previous studies (Arnot, Du Toit \& Bastos 2009; Thomson et al. 1983), but the adult to nymph ratio of 39\%:61\% was nearly three-fold higher than the average adult to nymph ratio of $13 \%: 87 \%$ from a previous tick survey conducted in South Africa (Thomson et al. 1983). This adult bias is important, as there is an on average nine-fold higher
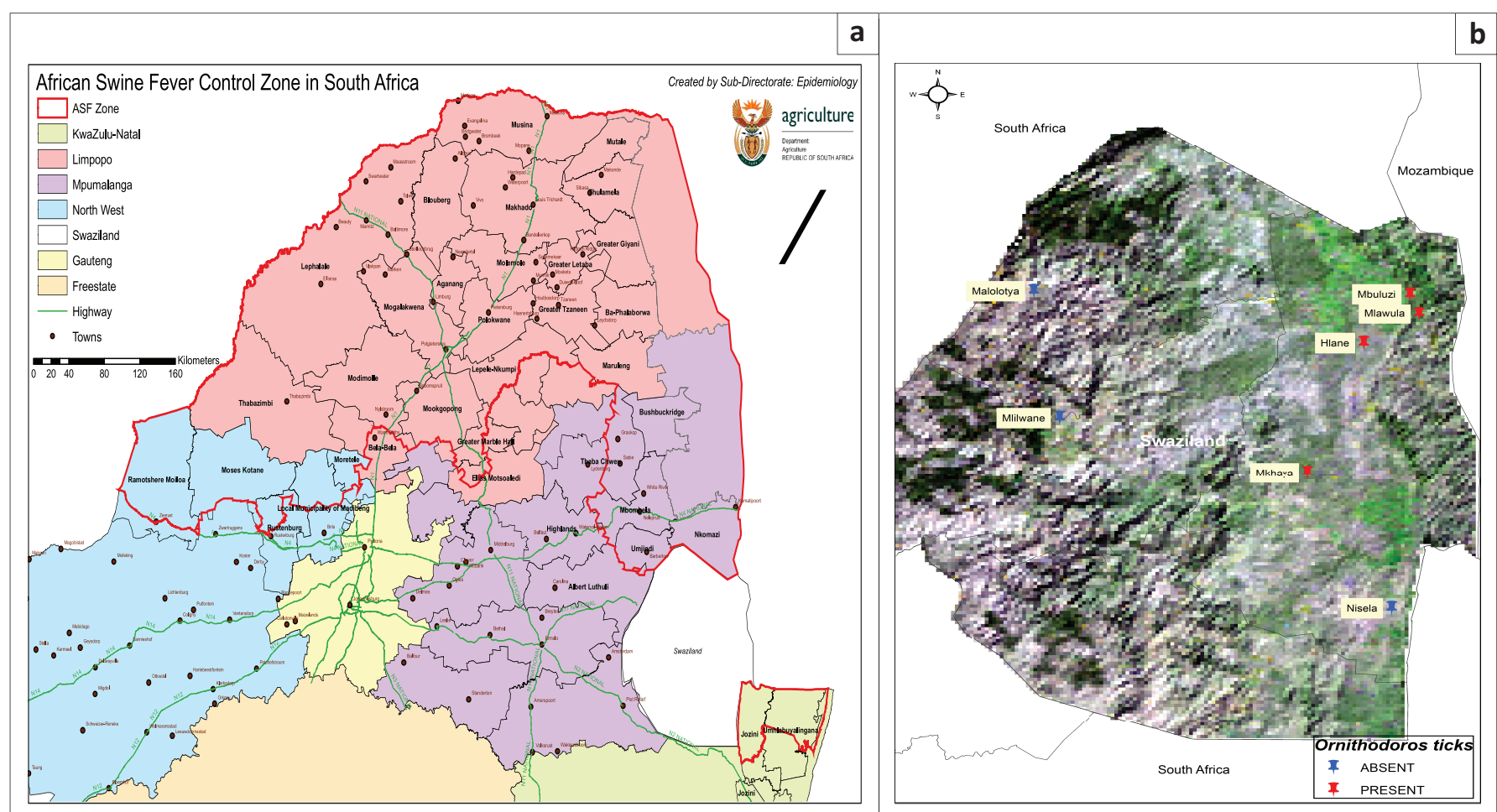

Source: (a) Department of Agriculture, Forestry and Fisheries (DAFF), Directorate Animal Health, n.d., Disease maps, viewed 14 January 2014, from http://www.nda.agric.za/vetweb/Epidemiology/ Disease\%20Maps/ASFcopy.pdf, (b) Map was drawn by Carin Boshoff with software ArcMap 10.2

FIGURE 1: Map indicating (a) Swaziland surrounded by the African Swine Fever control zone (indicated in red) and (b) the topography of Swaziland, the game reserves sampled in this study and Ornithodoros tick presence or absence. 


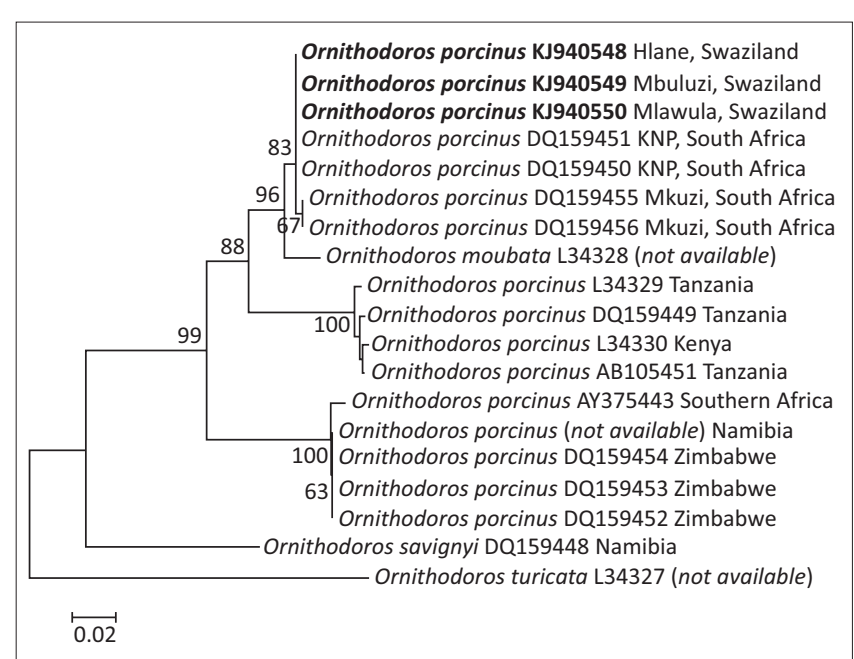

Source: Neighbour joining tree was drawn by Carin Boshoff with MEGA 5.2

FIGURE 2: Neighbour joining tree depicting 16S rRNA gene relationships of Ornithodoros ticks sampled from three Swaziland wildlife reserves.

infection rate in adults versus nymphs (calculated based on results of the Thomson et al. 1983 study). This, together with the 1.4 fold higher sensitivity of PCR versus isolation (Basto et al. 2006), mitigates concerns regarding the adequacy of the Swaziland sample size and underscores the advantages of performing adult-tick-biased surveys (Arnot et al. 2009).

Sequencing of the host mitochondrial gene of ticks sampled from three infested reserves was used to confirm the Ornithodoros porcinus species designation and to evaluate phylogeographical variation through comparison to reference data from southern and East Africa. Bastos et al. (2009) identified three geographically distinct O. porcinus lineages, with South African samples clustering within the south-east lineage. The gene phylogeny (Figure 2) confirmed that the sampled soft ticks from Hlane, Mlawula and Mbuluzi game reserves in Swaziland are identical to each other and all fall within the geographically distinct $O$. porcinus southeast lineage (Bastos et al. 2009). The ticks from Swaziland had $100 \%$ and $99.63 \%$ pairwise sequence identities to ticks from two South African localities, namely the Kruger National Park (KNP) and Mkuze Game Reserve (MGR), respectively, across the gene region sequenced.

Swaziland is surrounded by countries and regions where ASF has previously been reported. In Mozambique, bordering Swaziland to the east, disease control is challenging and the disease is known to be endemic in the country (Penrith et al. 2007). In South Africa, the disease is endemic in Mpumalanga province, which borders Swaziland to the north, and measures that prevent contact between pigs and sylvatic hosts of ASFV are implemented with success to prevent spread of the disease. In a study performed in MGR, in KwaZulu-Natal Province, which borders Swaziland to the south, it was shown that the virus was not present in any of the ticks sampled, signalling a possible change in the ASF status of this game reserve since the last survey in the late 1970s (Arnot et al. 2009). Together, these negative results from Swaziland and Mkuze, once substantiated with additional, more extensive studies, will assist in delineating, with greater confidence, the southernmost distributional range of ASF-positive ticks in South Africa.

Swaziland has an estimated population of 42000 domestic pigs, but as the country is presumed to be ASF negative, there are no bio-security measures in place to prevent the spread of the disease. As ASF is an economically important disease with implications for all burgeoning pig industries across sub-Saharan Africa (Penrith et al. 2013), the apparent absence of the virus indicated by this preliminary PCR-based tick assessment suggests that Swaziland should continue to focus efforts on minimising incursions in order to retain this status.

\section{Conclusion and future research}

Fifty-eight burrows were examined for the presence of Ornithodoros ticks from seven nature reserves in Swaziland. A total of 562 ticks were tested for the presence of ASFV. The relatively low number of warthog burrows and ticks was likely due to topography and to the relatively low numbers of warthogs in the parks, as no warthogs were observed by the sampling team. The hypothesis that ASFV may be absent from sylvatic cycle hosts in Swaziland needs to be more fully investigated. It is proposed that parks in adjacent countries forming part of the trans-frontier parks be sampled to confirm the presence or absence of the ticks and the virus. The preliminary results highlight the need for additional research, including serological surveys of warthogs in all the parks and of domestic pigs across the country, and testing of these wild suids and domestic pigs for prior exposure to Ornithodoros ticks with an enzyme-linked immunosorbent assay (ELISA) capable of detecting OpTSGP1 argasid salivary protein antibodies (Díaz-Martín et al. 2011) in order to clarify all epidemiological aspects that impact ASF status in Swaziland.

\section{Acknowledgments}

The authors wish to thank the Ministry of Agriculture, Swaziland for permission to perform this study, Jason Kilian and Sean Nord for providing field assistance, and Lara Nicholson and Eduard Roos for laboratory assistance. This research was supported by European Community's Seventh Framework Programme (FP7/2007-2013) under grant agreement KBBE- 211691- ASFRISK.

\section{Competing interests}

The authors declare that they have no financial or personal relationship(s) that may have inappropriately influenced them in writing this article.

\section{Authors' contributions}

C.I.B. (Agricultural Research Council-Onderstepoort Veterinary Institute) performed all of the experiments and prepared the manuscript. A.D.S.B. (University of Pretoria) assisted with the data analysis and preparation of the manuscript. M.M.D. (Central Veterinary Laboratory) was 
responsible for sample collection approval and coordinating the fieldwork in Swaziland. L.H. (Agricultural Research Council-Onderstepoort Veterinary Institute) was responsible for funding and preparation of the manuscript.

\section{References}

Arnot, L.F., Du Toit, J.T. \& Bastos, A.D., 2009, 'Molecular monitoring of African swine fever virus using surveys targeted at adult Ornithodoros ticks: A re-evaluation of Mkuze game reserve, South Africa', Onderstepoort Journal of Veterinary Research 76, 385-392. http://dx.doi.org/10.4102/ojvr.v76i4.22

Atlapedia, Swaziland, 1993-2011, viewed 10 August 2014, from http://www. atlapedia.com

Basto, A.P., Portugal, R.S., Nix, R.J., Cartaxeiro, C., Boinas, F., Dixon, L.K. et al., 2006 'Development of a nested PCR and its internal control for the detection of African swine fever virus (ASFV) in Ornithodoros erraticus', Archives of Virology 151, 819826. http://dx.doi.org/10.1007/s00705-005-0654-2

Bastos, A.D., Penrith, M.L., Crucière, C., Edrich, J.L., Hutchings, G., Couacy-Hymann, F.E. \& Thomson, G.R., 2003, 'Genotyping field strains of African swine fever virus by partial $p 72$ gene characterisation', Archives of Virology 148, 693-706. http:// dx.doi.org/10.1007/s00705-002-0946-8

Bastos, A.D., Arnot, L.F., Jacquier, M.D. \& Maree, S., 2009, 'A host speciesinformative internal control for molecular assessment of African swine fever virus infection rates in the African sylvatic cycle Ornithodoros vector', Medical and Veterinary Entomology 23, 399-409. http://dx.doi.org/10.1111/j.13652915.2009.00828.x

Boom, R., Sol, C.J., Salimans, M.M., Jansen, C.L., Wertheim-van Dillen, P.M. \& Van der Noordaa, J., 1990, 'Rapid and simple method for purification of nucleic acids', Journal of Clinical Microbiology 28, 495-503.

Department of Agriculture, Forestry and Fisheries (DAFF), Directorate Animal Health n.d., Disease maps, viewed 14 January 2014, from http://www.nda.agric.za/ vetweb/Epidemiology/Disease\%20Maps/ASFcopy.pdf

Díaz-Martín, V., Manzano-Román, R., Siles-Lucas, M., Oleaga, A. \& Pérez-Sánchez, R., 2011, "Cloning characterization and diagnostic performance of the salivary lipocalin protein TSGP1 from Ornithodoros moubata' Veterinary Parasitology 178(1-2), 163-172. http://dx.doi.org/10.1016/j.vetpar.2010.12.014
Embassy of the Kingdom of Swaziland And Mission to the European Communities: Country facts, viewed 10 August 2014, from http://www.swaziembassy.be

Food and Agriculture Organization (FAO), 2011, Swaziland Agricultural Development Programme (SADP), viewed 17 September 2014, from http://Www.fao. org/fileadmin/user_upload/oed/docs/1 Swaziland\%20Agricultural\%20 Development\%20Programme_2011_ER.pdf

Haresnape, J.M. \& Mamu, F.D., 1986, 'The distribution of ticks of the Ornithodoros moubata complex (Ixodoidea: Argasidae) in Malawi and its relation to African swine fever epizootiology', Journal of Hygiene, Cambridge 96, 535-544. http:// dx.doi.org/10.1017/S0022172400066341

Jori, F. \& Bastos, A.D.S., 2009, 'Role of wild suids in the epidemiology of African swine fever', EcoHealth 6, 296-310. http://dx.doi.org/10.1007/s10393-009-0248-7

Jori, F., Vial, L., Penrith, M.L., Pérez-Sánchez, R., Etter, E., Albina, E. et al., 2013, 'Review of the sylvatic cycle of African swine fever in sub-Saharan Africa and the Indian Ocean', Virus Research 173, 212-227. http://dx.doi.org/10.1016/j. virusres.2012.10.005

King, A.M.Q., Adams, M.J., Carstens, E.B. \& Lefkowitz, E.J. (eds.), 2012, The International Committee on Taxonomy of Viruses (ICTV) The International Code of Virus Classification and Nomenclature, Virus Taxonomy - Ninth Report of the International Committee on Taxonomy of Viruses, Elsevier/Academic Press, London, United Kingdom, pp. 153-162.

Penrith, M-L., Thomson, G.R. \& Bastos, A.D.S., 2004, 'African swine fever', in J.A.W. Coetzer \& R.C. Tustin (eds.), Infectious Diseases of Livestock, 2nd edn., pp. 1087-1119, Oxford University Press, Cape Town.

Penrith, M.L., Lopes Pereira, C., Lopes da Silva, M.M., Quembo, C., Nhamusso, A \& Banze, J., 2007, 'African swine fever in Mozambique: Review, risk factors and considerations for control', Onderstepoort Journal of Veterinary Research 74 149-160.

Penrith, M-L., Vosloo, W., Jori, F. \& Bastos, A.D.S., 2013, 'African swine fever virus eradication in Africa', Virus Research 173, 228-246. http://dx.doi.org/10.1016/j. virusres.2012.10.011

Tamura, K., Peterson, D., Peterson, N., Stecher, G., Nei, M. \& Kumar, S., 2011, 'MEGA5: Molecular Evolutionary Genetics Analysis using Maximum Likelihood, Evolutionary Distance, and Maximum Parsimony Methods', Molecular Biology and Evolution 28, 2731-2739. http://dx.doi.org/10.1093/molbev/msr121

Thomson, G., Gainaru, M., Lewis, A., Biggs, H., Nevill, E., Van der Pypekamp, H. et al., 1983, 'African Swine Fever. The relationship between African swine fever virus, the warthog and Ornithodoros species in southern Africa', in P.J. Wilkinson (ed.) Commission of the European Communities, Report EUR 2466 EN, pp. 85-100. 